\title{
ZAKAT PRODUKTIF SEBAGAI SALAH SATU SOLUSI PENGENTASAN KEMISKINAN DAN PENGANGGURAN DI INDONESIA
}

\author{
Oleh: Elfadhli* \\ Program Studi Perbankan Syariah STAIN Batusangkar \\ J1. Jenderal Sudirman No. 137, Lima Kaum Batusangkar \\ e-mail: amrilelfadhli@yahoo.co.id
}

\begin{abstract}
Indonesia, as one of the majority Moslem population in the world, is potentially promising for the growth and the development of zakah (divine tax) program, especially property, and to be made more productive, both in terms worships and practices of Islamic values, and economic activities in general. By means of zakah raising institution $(B A Z)$, the process of raising and distributing of zakah will be more effective and guaranteed. Furthermore, zakah is believed to be able to solve problems dealing with poverty resulting from the increase numbers of unemployement. Productive zakab, for example, give an opportunity for the zakah receivers to make use the money or property to start a new better life.
\end{abstract}

Kata kunci: productive tithe/zakah, distribution, unemployment, eradicate poverty

\section{PENDAHULUAN}

Ilam adalah agama yang sebagai kelanjutan dan penyempurnaan agama yang dibawa oleh para Nabi sebelumnya (Kaelany, 2000: 1). Tujuannya adalah untuk mencari keselamatan hidup materi dan keselamatan hidup spritual, yang dalam istilah agama disebut keselamatan dunia dan akhirat, dan dijelaskan dalam Q.S. al-Baqarah: 201.

Jalan keselamatan dunia dan akhirat itu ialah penyerahan diri kepada Tuhan pencipta alam semesta dengan cara mematuhi perintah-Nya dan menjauhi laranganNya dan dijelaskan Allah dalam firman-Nya Q.S. al-An'am: 155.
Akidah merupakan suatu sikap yang menunjukkan kepercayaan dan pengakuan terhadap rukun iman yang enam. Syariat mengembangkan dua pokok yang penting dan telah banyak dilakukan oleh umat muslim yaitu ibadah dan mu'amalah. Di dalam ibadah dijelaskan bagaimana kita beribadah kepada Allah dalam hal shalat, bagaimana kita mensucikan harta dengan zakat, dan lainlain. Sedangkan dalam mu'amalah membahas tentang hukum, pendidikan, sosial budaya, ekonomi, politik dan pemerintahan, filsafat, dan IPTEK. (Kaelany, 2000: 57).

Mu'amalah merupakan hubungan horizontal terhadap sesama manusia dan hubungan manusia dengan lingkungannya (Kaelany, 2000: 201). Dalam konteks inilah

* Penulis adalah Dosen pada Mata Kuliah Manajemen Dana Bank 
Islam memberikan tekanan pada keseimbangan kehidupan, yakni memandang kehidupan di dunia sama pentingnya dengan kehidupan di akhirat kelak. Selain itu, Islam pun memandang kehidupan dunia sama pentingnya dengan pembangunan kehidupan sosial, mencari nafkah untuk kehidupan dunia sama pentingnya dengan pergi ke masjid untuk beribadah. Islam tidak melarang penganutnya untuk berusaha mencari harta, hanya saja ketika seseorang sudah berhasil mendapatkan harta, maka harus diingat bahwa di dalam harta itu terdapat hak orang lain (Umrotul Khasanah, 2010: 2). Dengan bermuamalah akan memperkuat rasa solidaritas antara sesama manusia, menumbuhkan rasa saling menyayangi serta dapat meningkatkan semangat hidup manusia, khususnya dengan adanya zakat.

Zakat merupakan salah satu rukun Islam dan merupakan kewajiban agama yang dibebankan atas harta kekayaan seseorang menurut aturan tertentu (Mohammad Daud Ali, 1988: 9). Zakat sangat berpengaruh dalam menangani permasalahan pengangguran dan kemiskinan di Indonesia. Contohnya dengan pemberdayaan zakat, orang yang tidak mempunyai modal menjadi memiliki modal untuk berusaha, serta dapat meratakan perekonomian masyarakat. Tujuannya adalah untuk mensucikan harta dengan harapan pada akhirnya semua masyarakat tidak ada lagi yang menerima zakat, semua masyarakat pada akhirnya diharapkan menjadi orang yang berzakat. Namun, kita tidak bisa menebak semaksimum apakah zakat mampu mengatasi pengangguran dan kemiskinan di Indonesia. Apalagi didukung dengan tingginya zakat yang diperoleh seharusnya bisa mengurangi kemiskinan dan pengangguran khususnya, serta adanya lembaga khusus yang mengambil bagian dalam hal pengumpulan dan pengelolaan zakat seperti BAZ dan LAZ. Pertanyaannya adalah sejauh mana harta zakat ini dikembangkan dan didayagunakan kepada masyarakat. Apakah ada dampak positif yang ditimbulkan seperti perubahaan ekonomi masyarakat ke arah yang lebih baik atau hanya tetap begitu saja. Serta seperti apa seharusnya zakat dikembangkan.

\section{PENGERTIAN ZAKAT}

Zakat menurut etimologi (bahasa) adalah suci, tumbuh berkembang, dan berkah (M. Ali Hasan, 1997: 01). Sebagaimana firman Allah dalam Q.S: Asy-Syam: 9. Maksud kata zakka dalam ayat tersebut ialah menyucikan dari kotoran. Arti yang sama (suci) juga terlihat dalam ayat tersebut.

Menurut terminologi zakat adalah kadar harta tertentu yang diberikan kepada yang berhak menerimanya, dengan syarat tertentu. (M. Ali Hasan, 1997: 01)

Zakat ialah hak tertentu yang diwajibkan Allah SWT terhadap kaum Muslimin yang diperuntukkan bagi mereka, yang dalam Quran disebut kalangan fakir miskin dan mustahik lainnya, sebagai tanda syukur atas nikmat Allah SWT dan untuk mendekatkan diri kepadaNya, serta untuk membersihkan diri dan hartanya. 
Menurut Imam Maliki dalam mendefinisikan zakat bahwa zakat adalah mengeluarkan sebagian yang khusus dari harta yang khusus pula yang telah mencapai nishab (batas kuantitas yang mewajibkan zakat) kepada orang-orang yang berhak menerimanya dengan catatan kepemilikan itu penuh dan mencapai haul, bukan barang tambang dan bukan pertanian.

Menurut madzhab Syafi'i zakat adalah sebuah ungkapan untuk keluarnya harta atau tubuh sesuai dengan cara khusus, sedangkan madzhab Hambali mengatakan zakat adalah hak yang wajib dikeluarkan dari harta yang khusus untuk kelompok yang khusus pula. (Wahbah Al Zuhayly, 1995: 83-85)

\section{SEJARAH ZAKAT DARI MASA KE MASA}

Dalam sejarah perjalanannya zakat merupakan suatu institusi yang cukup unik dan menarik bila kita perhatikan karena selalu mengalami perubahan setiap waktu dan masa, walaupun ia merupakan ketetapan Ilahi. Dalam sejarahnya terdapat beberapa periode, diantaranya: (Zaidi Abdad, 2003: 22-25)

\section{Pada Awal Islam (Periode Mekah)}

Zakat merupakan kewajiban yang sepenuhnya diserahkan pada masing-masing kaum muslimin, sehingga bergantung pada kadar keimanan mereka. Kadar keimanan yang tinggi seolah-olah digambarkan dengan zakat yang besar, dan sebaliknya, karena belum adanya ketetapan kadar zakat, jenis apa saja yang harus dizakati, sehingga mengakibatkan zakat pada periode ini belum memiliki dampak sosial ekonomi yang luas.

\section{Periode Madinah}

Pada tahun kedua Hijriah dalam periode Madinah, zakat mulai disyari'atkan Allah dan dijalankan pelaksanaan hukumnya dengan tegas dan rinci. Zakat telah diwajibkan, ukuran atau kadarnya ditentukan dari tiap-tiap macam harta dengan jelas dan rinci serta dibudayakan dalam masyarakat masih sangat utuh seperti yang dipahami Nabi dari wahyu Allah, baik yang diterima secara langsung maupun tidak langsung.

Setelah wafatnya Nabi, zakat terus berkembang. Tahap pertama dikembangkan oleh para sahabat dan dibudidayakan dalam masyarakat Islam dan terus berkembang hingga terbentuk komunitas yang sangat besar. Para sahabat terutama para khalifah yang empat membuat berbagai ketetapan baru untuk menghadapi permasalahan yang timbul, seperti ketetapan tidak memberikan zakat kepada mu'allaf oleh khalifah Umar karena umat Islam dianggap sudah kuat.

\section{Pada Masa Imam Mujtahid}

Pada masa ini, zakat terus berkembang. Namun, seiring perjalanan waktu terjadi perselisihan diantara mereka, sehingga melahirkan berbagai aliran fiqih yang dibakukan dan dibudayakan dalam masyarakat yang disebut madzhab. Kemudian masing-masing madzhab mengembangkan hukumnya ke dalam masyarakat. 
Pada tahun kedua Hijriah, merupakan perkembangan hukum zakat sebagai salinan sunnatullah menjadi sunnatul insani yang memiliki nuansa kebudayaan, karena itu disebut dengan fenomena kebudayaan. Maksudnya, ketentuan hukum yang telah ditelaah, digali, dan dirumuskan oleh mujtahid telah diajarkan, dihayati, dikristalisasikan, diamalkan, serta diwariskan terus menerus. Ketentuan-ketentuan yang dikeluarkannya disebut dengan fatwa. Setelah Imam Mujtahid besar tidak ada, maka hukum zakat terus mengalami perkembangan dan dibudayakan, dan hukum-hukum yang ada semakin melekat dalam mentalisasi masyarakat.

Contoh dalam perjalanan zakat mulai masa Nabi sampai pada masa tabi'in adalah tentang harta benda yang wajib dizakati. Di masa Nabi zakat masih berkisar pada binatang ternak seperti kambing, sapi, unta, barang-barang yang berharga seperti emas dan perak, tumbuh-tumbuhan seperti jelai, gandum, anggur kering dan kurma. Kemudian, seiring berjalannya waktu diberlakukannya sifat penerimaan untuk diperkembangkan pada harta tersebut yang dinamakan 'illat. Berdasarkan 'illat inilah ditetapkan hukum zakat. Misalnya hewan kuda di masa Nabi tidak diwajibkan zakat padanya karena kuda hanya diperlukan untuk peperangan, sebaliknya pada masa Umar bin Khattab dikenakan zakat atas kuda karena kuda pada masa ini sudah dikembangkan melalui peternakan.
HUKUM MENGELUARKAN ZAKAT

Zakat merupakan rukun ketiga dari lima rukun Islam dan zakat juga termasuk salah satu panji-panji Islam yang penegakkannya tidak boleh diabaikan oleh siapaun juga. Zakat telah difardhukan di Madinah pada bulan Syawal tahun kedua hijrah setelah kepada umat Islam diwajibkan berpuasa Ramadhan. Dasardasar atau landasan kewajiban mengeluarkan zakat disebutkan dalam Al Qur'an: QS. Al Baqarah: 43, QS. At Taubah: 103. (Saleh Al Fauzan, 2006: 244)

Selain di dalam al-Qur'an dasar-dasar atau landasan kewajiban mengeluarkan zakat disebutkan dalam hadits yang diriwayatkan oleh Bukhari dan Muslim dari Abdullah bin Umar Rasulullah bersabda: "Islam itu ditegakkan atas lima pilar: syahadat yang menegaskan bahwa tiada Tuhan selain Allah dan Muhammad utusan Allah, mendirikan sholat, membayar zakat, menunaikan haji dan berpuasa pada bulan Ramadhan" (HR Bukhari Muslim). (Syaikh Muhammad Abdul Malik Ar Rahman, 2003:12)

Adapun hadits lain yang diriwayatkan oleh Ahmad dan Muslim dari Abu Hurairah: "Seseorang yang menyimpan hartanya tidak dikeluarkan zakatnya akan dibakar dalam neraka jahannam baginya dibuatkan seterika dari api, kemudian diseterikakan ke lambung dan dahinyaAl Hadits (HR Ahmad dan Muslim). (Sulaiman Rasyid, 1994:193)

Selain al-Qur'an dan sunnah terdapat ijma' ulama' yang telah sepakat akan kewajiban zakat dan bagi yang mengingkarinya berarti 
telah kafir dari Islam. Ulama yang menyepakati ini adalah ulama salaf (tradisional) maupun khalaf (modern). (Syaikh Muhammad Abdul Malik Ar Rahman, 2003: 17)

\section{SYARAT DAN RUKUN ZAKAT}

Zakat mempunyai beberapa syarat wajib dan syarat sah. Menurut jumhur ulama syarat wajib zakat terdiri dari:

1. Islam

2. Merdeka

3. Baligh dan berakal

4. Harta yang dikeluarkan adalah harta yang wajib dizakati.

5. Harta yang dizakati telah mencapai nishab atau senilai dengannya.

6. Harta yang dizakati adalah milik penuh.

7. Kepemilikan harta telah mencapai haul (setahun).

8. Harta tersebut bukan termasuk harta hasil hutang.

9. Harta yang akan dizakati melebihi kebutuhan pokok.

Dan diantara syarat-syarat sah pelaksanaan zakat terdiri atas:

1. Niat

2. Tamlik (memindahkan kepemilikan kepada penerimanya).

Rukun zakat adalah mengeluarkan sebagian dari nisab (harta) yang dengan melepaskan kepemilikan terhadapnya, menjadikannya sebagai milik orang fakir dan menyerahkan kepadanya atau harta tersebut diserahkan kepada wakilnya yakni imam atau orang yang bertugas untuk memungut zakat. (Syaikh Muhammad Abdul Malik Ar Rahman, 2003: 97)

\section{JENIS JENIS ZAKAT}

\section{Zakat Fitrah}

Makna zakat fitrah, yaitu zakat yang sebab diwajibkannya adalah futur (berbuka puasa) pada bulan Ramadhan disebut pula dengan sedekah. Lafadz sedekah menurut syara' dipergunakan untuk zakat yang diwajibkan, sebagaimana terdapat pada berbagai tempat dalam al-Qur'an dan sunnah. Dipergunakan pula sedekah itu untuk zakat fitrah, seolah-olah sedekah dari fitrah atau asal kejadian, sehingga wajibnya zakat fitrah untuk mensucikan diri dan membersihkan perbuatannya.

Zakat Fitrah, zakat yang wajib dikeluarkan Muslim menjelang Idul Fitri pada bulan Ramadhan. Besar zakat ini setara dengan 2,5 kilogram/3,5 liter makanan pokok yang ada di daerah bersangkutan. Zakat maal (zakat harta), mencakup hasil perniagaan, pertanian, pertambangan, hasil laut, hasil ternak, harta temuan, emas dan perak. Masingmasing tipe memiliki perhitungannya sendiri-sendiri.

Adapun dalil atau dasar kewajibannya zakat fitrah adalah berdasarkan QS: al-Baqarah: 43. Adapun hadis dari Ibn Umar ia berkata: Rasulullah SAW mewajibkan zakat fitri (berbuka) bulan Ramadhan sebanyak satu sha'(3,1 liter) kurma atau gandum atas tiap-tiap orang muslim merdeka atau hamba, laki-laki atau perempuan"(HR Bukhari Muslim), dalam hadits Bukhari disebutkan "mereka membayar fitrah itu sehari atau dua hari sebelum hari raya". (Saleh Al Fauzan, 2006: 272) 
Adapun syarat-syarat wajib zakat fitrah terdiri atas:

1. Islam.

2. Lahir sebelum terbenam matahari pada hari penghabisan bulan Ramadhan.

3. Memiliki kelebihan harta dan keperluan makanan untuk dirinya sendiri dan untuk yang wajib dinafkahinya baik manusia ataupun binatang pada malam hari raya dan siang harinya.

\section{Zakat Maal (Harta)}

Menurut terminologi (bahasa) harta adalah segala sesuatu yang diinginkan sekali oleh manusia untuk memiliki, memanfaatkan dan menyimpannya. Sedangkan menurut istilah syara' harta adalah segala sesuatu yang dapat dimiliki dan dapat dimanfaatkan. Sesuatu dapat disebut dengan maal (harta) apabila memenuhi dua syarat antara lain:

1. Dapat dimiliki, dikuasai, dihimpun dan disimpan.

2. Dapat diambil manfaatnya sesuai dengan ghalibnya seperti rumah, mobil, ternak, dan lain sebagainya.

Harta (maal) yang wajib dizakati:

1. Binatang ternak seperti: unta, sapi, kerbau, kambing, domba, dan unggas (ayam, itik, burung).

2. Emas dan perak.

3. Biji makanan yang mengenyangkan seperti beras, jagung, gandum, dan sebagainya.

4. Buah-buahan seperti anggur dan kurma.

5. Harta perniagaan.

Masing-masing golongan harta kekayaan ini berbeda nisab yakni jumlah minimum harta kekayaan yang wajib dikeluarkan zakatnya, haul yaitu jangka waktu yang ditentukan bila seseorang wajib mengeluarkan zakat hartanya, dan qadar zakatnya yakni ukuran besarnya zakat yang harus dikeluarkan.

\section{MUSTAHIQ}

Mustahiq berasal dari bahasa arab dengan kata dasar استحق yang artinya berhak (Mahmud Yunus, 1989: 106). Kata mustahiq sebagai turunannya orang yang berhak. Jadi mustahiq zakat adalah orang-orang yang berhak menerima zakat.

Mengenai orang yang berhak menerima zakat telah Allah jelaskan dalam QS: At-Taubah: 60. Dari Ayat tersebut Allah menyebutkan bahwasanya ada 8 golongan orang-orang yang berhak menerima zakat, yaitu: fakir, miskin, amil, yaitu orang yang mengurus zakat, muallaf, yaitu orang yang baru masuk Islam yang masih lemah imannya, riqab, yaitu hamba sahaya atau budak belian yang diberi kebebasan berusaha untuk menebus dirinya supaya menjadi orang merdeka, gharim, yaitu orang yang berhutang, sabilillah arti harfiahnya yaitu jalan Allah. Maknanya adalah segala usaha yang baik yang dilakukan untuk kepentingan agama dan ajaran Islam, ibnu sabil, yaitu orang yang kehabisan biaya dalam perjalanan yang bermaksud baik. (Mohammad Daud Ali, 1988: 26-27) 


\section{PERKEMBANGAN ZAKAT MAAL DI INDONESIA}

Sebagaimana yang telah penulis jelaskan di atas, pengumpulan zakat telah ada sejak zaman Rasulullah SAW. Kemudian ditetapkan sebagai kewajiban oleh khalifah setelah wafatnya Rasulullah. Hingga tidak ada lagi masyarakat pada waktu itu yang menerima zakat.

Namun, di tanah air pun sudah ada sejak Islam datang. Pada waktu itu zakat menjadi sumber dana untuk kepentingan pengembangan agama Islam. Dalam perjuangan bangsa Indonesia menentang penjajahan Barat dahulu, zakat, terutama bagian sabilillahnya, merupakan sumber dana perjuangan.

Pada dasarnya zakat bukanlah pajak yang merupakan sumber pendapatan negara. Lembaga zakat sangat penting dalam menyusun kehidupan yang humanis dan harmonis. Peranan zakat, baik zakat harta maupun zakat fitrah, dalam pemerataan pendapatan akan lebih kentara kalau dihubungkan dan dilaksanakan bersama dengan nilai instrumental lainnya yakni pelarangan riba. (Mohammad Daud Ali, 1988: 9)

Masyarakat sangat berharap dengan adanya lembaga zakat, karena mampu menjalankan fungsi dan perannya secara baik yakni mampu mengelola zakat sebagaimana mestinya. Kita ketahui bahwasanya zakat mampu mengurangi beban dan bisa menjadikan orang yang awalnya tidak mempunyai modal, hingga mampu membiayai kehidupannya.

Selain itu zakat juga mempunyai manfaat bagi orang yang memberikan zakat tersebut, yakni akan memperoleh pahala yang besar dari Allah SWT, yakni berupa kebaikan (pahala) melebihi dari apa yang telah diberikannya pada orang lain.

\section{PENDAYAGUNAAN HARTA ZAKAT SECARA PRODUKTIF}

Sebagaimana yang telah kita ketahui bahwasanya pendayagunaan harta zakat secara umum dapat dibedakan menjadi dua macam, yaitu pendayagunaan harta zakat dalam bentuk konsumtif-karitatif dan produktif-berdayaguna. Maksud konsumtif disini adalah harta zakat secara langsung diperuntukkan bagi mereka yang tidak mampu dan sangat membutuhkan, terutama fakir miskin. Harta zakat diarahkan terutama untuk memenuhi kebutuhan pokok hidupnya, seperti kebutuhan makanan, pakaian dan tempat tinggal secara wajar.

Kebutuhan pokok yang bersifat primer ini terutama dirasakan oleh kelompok fakir, miskin, garim, anak yatim piatu, orang jompo atau cacat fisik yang tidak bisa berbuat apapun untuk mencari nafkah demi kelangsungan hidupnya.

Pendayagunaan harta zakat secara produktif sebagian ulama sebagaimana dalam kitab-kitab kuning, mereka sesungguhnya telah melangkah jauh, di mana ketika menetapkan perlunya pemberian kepada fakir miskin untuk memenuhi kebutuhan hidupnya, juga adanya pemberian harta zakat kepada mereka para mustahiq secara produktif. Harta zakat secara produktif artinya harta zakat yang dikumpulkan dari muzakki tidak 
habis dibagikan secara begitu saja untuk memenuhi kebutuhan yang bersifat konsumtif, melainkan harta zakat itu sebagian ada yang diarahkan pendayagunaannya kepada yang bersifat produktif. (Mu'inan Rafi', 2011:130-132) Jadi, harta zakat tersebut dikelola, dikembangkan sedemikian rupa sehingga bisa mendatangkan manfaat (hasil), yang mana hasilnya tersebut akan digunakan untuk memenuhi kebutuhan orang tersebut.

Mengenai pendayagunaan harta zakat secara produktif ini, sebagian ulama dari golongan Syafi'iyyah sebagaimana dalam Hasyiyah as Syaikh Ibrahim al-Bajuri mengemukakan bahwa orang fakir miskin diberi harta zakat yang cukup untuk biaya hidupnya menurut ukuran umum yang wajar. Atau dengan harta zakat itu fakir miskin dapat membeli tanah untuk kemudian digarapnya. Begitu juga dengan pemerintah juga bisa membelikan tanah untuk fakir miskin dari harta zakat. Sehingga, mereka bisa menggarap lahan tersebut.

Selain itu, harta zakat juga bisa digunakan untuk investasi produktif, membiayai macam-macam proyek pembangunan dalam bidang pendidikan, pemeliharaan kesehatan, air bersih, dan aktifitas-aktfitas kesejahteraan sosial yang lain, yang dipergunakan semata-mata untuk kepentingan fakir miskin. Pendapatan fakir miskin diharapkan bisa meningkat sebagai hasil dari produktifitas mereka yang lebih tinggi (Mu'inan Rafi', 2011: 133-134). Pendayagunaan harta zakat secara produktif dan berdayaguna dibenarkan oleh syara', selama harta zakat tersebut tetap diarahkan ke segala usaha dan bidang yang menyangkut kebutuhan manusia seutuhnya, lahiriyah dan batiniyah bagi golongan fakir miskin untuk menyelamatkannya dari ketidak-mampuannya serta dapat meningkatkan harkat dan martabat manusiawinya. Pendayagunaan harta zakat secara produktif, edukatif, dan ekonomis untuk konteks sekarang ini sangat diperlukan. Karena dengan pendayagunaan harta zakat secara produktif tersebut oleh mustahiq tidak habis begitu saja, melainkan bisa dikembangkan sesuai dengan kehendak dan tujuan dari syari'at zakat, yaitu menghilangkan kemiskinan serta mensejahterakan bagi kaum dhuafa, dengan harapan secara bertahap mereka tidak selamanya menjadi mustahiq melainkan menjadi muzakki. (Mu'inan Rafi', 2011:142) Dengan begitu harta zakat bisa berkembang sehingga akan menjadi jumlah yang cukup banyak. Pengembangan ini tetap diarahkan untuk membantu menyantuni mustahiq zakat menuju kemandirian mereka.

Memperhatikan perekonomian Indonesia saat ini, sangat diperlukan sebuah lembaga yang mampu mengelola zakat secara efektif dan efesien sesuai dengan ketentuan syari'at. Objek zakat harus mengalami perkembangan bukan hanya yang tertulis pada kitab-kitab kuning masa silam. Prosentase perekonomian yang ada sekarang ini bukan lagi bertumpu pada sektor pertanian, perkebunan, dan peternakan tradisional, melainkan mengarah sektor industri dan jasa. Demikian halnya pendistribusian dan pendayagunaan harta zakat secara produktif kepada 
delapan asnaf yang ada harus mengalami insterprestasi kontekstual atau tepatnya reinterpretasi ulang mengenai siapa yang dimaksud dalam asnaf delapan itu. Serta bagaimana pendayagunaannya (Mu'inan Rafi', 2011:146). Untuk mengatasi kesenjangan sosial dan kemiskinan yang menjadi kunci keberhasilan lembaga zakat adalah kepastian hukum pelaksanaan zakat, yang konsekuensinya langsung dilakukan oleh aparat negara.

Namun, sejak era reformasi yang menjadi kendala bagi pelembagaan zakat secara perlahan mulai terkuat antara lain dengan lahirnya Undang-undang No. 38 Tahun 1999 tentang Pengelolaan Zakat dan telah diubah dengan Undang-undang No. 23 Tahun 2011 yang dikuatkan dengan PP No. 14 tahun 2014. Sesuai dengan pasal-pasal dalam Undangundang tersebut, bahwa pemerintah tidak berfungsi sebagai operator yang mengelola zakat tetapi sebagai regulator, motivator, koordinator dan fasilitator. Pengelolaan zakat dilakukan oleh badan yang dibentuk pemerintah atau lembaga yang didirikan oleh masyarakat dan diberi otoritas formal melalui pengukuhan pemerintah.

\section{KEMISKINAN DAN MUSTAHIQ ZAKAT}

Masalah kemiskinan dan pengangguran muncul dalam wacana teori ekonomi sebagai akibat dari ketidakpastian terhadap kinerja teori-teori ekonomi dalam realitas pembangunan. Namun, teori ekonomi belum mampu secara optimum memecahkan masalah kemiskinan dan ketinggalan. Kemiskinan se- sungguhnya telah menjadi masalah yang akut sejak lama, dan hampir dapat dinyatakan kenyataan abadi. Kemiskinan dapat diukur dengan membandingkan total pendapatan rumah tangga dengan total kebutuhan rumah tangga. Masalah kemiskinan muncul karena adanya sekelompok anggota masyarakat yang secara struktural tidak mempunyai peluang dan kemampuan yang memadai untuk mencapai tingkat kehidupan layak. Persaingan yang tak seimbang membuat mereka tak unggul kian lama semakin tertinggal. Dalam proses ini menimbulkan persoalan ketimpangan distribusi pendapatan dan selanjutnya kesenjangan kesejahteraan.

Secara teoritis, kemiskinan merupakan akibat dari ketidaksesuaian dalam praktek ekonomi. Islam menganggap kegiatan ekonomi sebagai bagian aspek tanggung jawab sosial di dunia. Orang yang semakin terlibat dalam ekonomi akan menjadi semakin baik taraf hidupnya selama tetap terjaga keseimbangannya (Umrotul Khasanah, 2010: 28-32). Dalam mengurangi kemiskinan tersebut dapat dilakukan dengan memberi nasehat kepada mereka untuk tetap bersabar dan kepada kaum kaya untuk dapat mengeluarkan sebahagian dari hartanya karena sebagaimana yang telah dijelaskan sebelumnya bahwa di dalam harta kita ada harta orang lain yang harus kita keluarkan yakni dengan zakat. Sehingga akan tercipta hubungan yang harmonis, saling membutuhkan sehingga terjaga keseimbangan hidup bermasyarakat. 
Zakat merupakan sumber penting dalam struktur keuangan ekonomi Islam. Karena setiap muslim wajib membayar sebagian dari kekayaannya apabila telah mencapai satu nisab kepada orang yang berhak menerimanya. Dalam pengertian modern, zakat adalah pajak yang dikumpulkan dari orang kaya muslim yang diperuntukkan terutama untuk membantu masyarakat muslim yang miskin. Sehingga masyarakat menjadi sejahtera dan mecapai kemakmuran. Dengan begitu, jelas bahwasannya selain merupakan istrumen relijius, zakat juga sebagai instrumen fiskal untuk mencapai tujuan keadilan sosial ekonomi dan distribusi kekayaan dan pendapatan. Selain itu zakat juga bisa menjadi suplemen pendapatan permanen untuk orang yang tidak mampu menghasilkan pendapatan yang cukup, melalui usaha-usahanya sendiri, atau untuk kepentingan yang lain, sehingga zakat dapat digunakan untuk menyediakan pelatihan dan modal unggulan agar mereka dapat membentuk usaha-usaha kecil dan pada akhirnya mereka dapat berusaha secara mandiri. Zakat merupakan sebuah isntrumen yang berfungsi memutar roda ekonomi secara terus menerus dan tidak boleh berhenti.

\section{LEMBAGA ZAKAT DI INDO- NESIA}

Di Indonesia, organisasi pengelola zakat terbagi ke dalam dua jenis yaitu Badan Amil Zakat (BAZ), dan Lembaga Amil Zakat (LAZ). Struktur organisasi BAZ dan LAZ biasanya disusun berdasarkan pada kebutuhan spesifik masing-masing. Secara umum terdiri atas bagian penggerak dana, bagian keuangan, bagian pendayagunaan, dan bagian pengawasan. Kecuali, organisasi pengelola zakat juga harus memiliki Komite Penyaluran (Lending Committe) dengan mekanisme yang baik agar dana dapat tersalur kepada yang benar-benar berhak, yakni untuk menjadi saluran seleksi atas setiap distribusi dana yang akan dilakukan sesuai ketentuan syariah, prioritas dan kebijakan lembaga (Umrotul Khasanah, 2010: 64). Sehingga, dengan adanya lembaga yang mengumpulkan zakat akan lebih mengefektifkan pendistribusian zakat tentunya.

Dengan banyaknya pengangguran baik itu pengangguran terbuka, setengah menganggur atau pun menganggur sepenuhnya dapat diatasi jika diberlakukannya suatu peraturan oleh pemerintah akan kewajiban menunaikan zakat. Misalnya, dengan lima juta penduduk kemudian mereka memiliki penghasilan rata-rata Rp. 2.500.000,- per bulan kemudian mereka mengeluarkan zakat 2,5\% dari penghasilan yang mereka peroleh, maka akan terkumpul sebanyak Rp. 62.500,- per bulan. Jika dikumpulkan selama satu tahun akan berjumlah Rp. 312.500.000.000,-. Sebanyak itu dalam satu tahun jika efektif dan bisa dimanfaat seoptimal mungkin oleh lembaga zakat serta adanya ikut campur oleh pemerintah dalam pemungutan dana tersebut alangkah indahnya kehidupan masyarakat di Indonesia. Sebagian besar rakyat Indonesia adalah muslim dan juga banyaknya pejabat-pejabat negara 
seorang muslim, penulis yakin pembuatan kebijakan serta UndangUndang yang mengatur pemberdayaan zakat secara produktif akan sangat berpengaruh dalam perekonomian masyarakat dan negara.

\section{PENGELOLAAN ZAKAT OLEH NEGARA}

Menurut ajaran Islam, zakat sebaiknya dipungut oleh negara atau pemerintah yang bertindak sebagai wakil fakir miskin untuk memperoleh haknya yang ada pada harta orang kaya. Zakat pada hakekatnya adalah distribusi kekayaan di kalangan umat Islam, untuk mempersempit jurang pemisah antara orang kaya dan orang miskin dan menghindari penumpukan kekayaan di tangan seseorang. Keuntungannya apabila zakat dipungut oleh negara adalah para wajib zakat lebih disiplin dalam menunaikan kewajibannya dan fakir miskin lebih terjamin haknya, perasaan fakir miskin lebih dapat dijaga dan tidak merasa seperti orang yang meminta-minta, pembagian zakat akan menjadi lebih tertib, zakat yang diperuntukkan bagi kepentingan umum seperti sabilillah misalnya dan dapat disalurkan dengan baik karena pemerintah lebih mengetahui sasaran pemanfaatannya (Moham-mad Daud Ali, 1988:51-52), dana zakat dapat digunakan untuk mengelola dan mengembangkan potensi-potensi ekonomi rakyat yang bersifat produktif, seperti membuka lapangan kerja dan usaha yang diambil dari dana zakat atau memberikan bantuan modal untuk membuka usaha mandiri. (M. Djamal Doa, 2004: 18)
Zakat harus dikelola oleh pemerintah dengan beberapa alasan berikut:

1. Tidak optimalnya pemberdayaan kaum miskin oleh lembaga swasta dalam memerangi kemiskinan dan semakin banyaknya kelompok yang ingkar akan pembayaran zakat padahal zakat merupakan suatu kewajiban.

2. Zakat merupakan suatu kewajiban bagi pemeluk Islam.

3. Sebagian besar warga Indonesia adalah beragama Islam dan sebagian besar pemimpin Indonesia beragama Islam pula. (M. Djamal Doa, 2004: 2-6)

Jadi, zakat harus bisa dikelola oleh negara sebagai mana haji telah dikelola oleh negara. Beberapa strategi yang dilakukan oleh pemerintah dalam mengatasi masalah kemiskinan dan pengangguran, yaitu:

1. Menjaga stabilitas harga bahan kebutuhan pokok.

2. Mendorong pertumbuhan yang berpihak pada rakyat miskin.

3. Menyempurnakan dan memperluas cakupan program pembangunan berbasis masyarakat.

4. Meningkatkan akses masyarakat miskin kepada pelayanan dasar.

5. Membangun dan menyempurnakan sistem perlindungan sosial bagi masyarakat miskin.

\section{HAMBATAN DALAM PENGEM- BANGAN ZAKAT DALAM MASYARAKAT}

Sebagaimana yang kita ketahui, potensi zakat sangat besar terhadap perekonomian masyarakat Indonesia. Namun, masih ada masalah- 
masalah tertentu yang menghambat pelaksanaanya, yaitu:

1. Kurangnya pemahaman umat Islam tentang lembaga zakat.

2. Konsepsi fikih zakat. Maksudnya konsep pengertian dan pemahaman mengenai zakat hasil ijtihad manusia.

3. Pembenturan kepentingan. Jika pengumpulan zakat terkoordinasi dalam badan-badan baru, maka akan menimbulkan kekhawatiran kepentingannya akan terganggu seperti BAZ yang telah memungut zakat.

4. Hambatan politisi.

5. Sikap kurang percaya.

6. Sikap tradisional. (Mohammad Daud Ali, 1988: 53-56)

\section{SOLUSI DARI PERMASALAH- AN/HAMBATAN}

Untuk memecahkan beberapa masalah yang telah dikemukakan di atas, penulis mengajukan beberapa solusi, seperti berikut ini:

1. Penyebarluasan pengertian zakat, dapat melalui pendidikan baik formal maupun informal, penyuluhan terutama tentang hukumnya serta barang yang wajib dizakati, pendayagunaan dan pengorganisasiannya sesuai dengan perkembangan zaman. Dan menjelaskan bahwasanya kehidupan akhirat itu lebih kekal dari pada kehidupan dunia.

2. Membuat atau merumuskan fikih baru karena masyarakat Indonesia sekarang juga melakukan kegiatan produksi berupa industri, perniagaan, jasa, dan lain-lain.

3. Pendayagunaan dana yang tersedia. Yakni mampu menempatkan dana zakat sesuai dengan asnaf yang delapan. Dan memberikan pengertian zakat bukan hanya untuk konsumtif tapi juga bisa untuk produktif, sehingga tidak selamanya dia menerima zakat, akan tetapi akan menjadikan ia sebagi muzakki.

4. Dirumuskannya hukum atau Undang-undang yang mengatur tentang zakat poduktif berdayaguna. Karena, melihat kondisi ekonomi Indonesia saat ini lebih cenderung melakukan kegiatan ekonomi di bidang produksi, industri serta perniagaan. Karena menurut penulis, sangat besar zakat atas hal tersebut. Selain itu, pertanian, perdagangan dan halhal lain yang dibahas dalam ketentuan dalam zakat itu sudah mulai berkurang. Malahan industri, produksi, dan lain-lain lebih besar kemampuannya. Sehingga, jika lebih dikuatkan pada zakat produktif berdayaguna maka, pengangguran akan berkurang dan kemiskinan juga semakin sedikit.

Jadi, pada dasarnya zakat memang dipandang sebagai suatu kewajiban. Namun, pada dasarnya juga dapat membantu menanggulangi kemiskinan dengan adanya zakat produktif. Zakat produktif bisa menciptakan lapangan pekerjaan yang meningkatkan penghasilan. Berarti, dengan sendirinya zakat juga mampu mengurangi pengangguran dan memberantas kemiskinan.

\section{CONTOH APLIKASI ZAKAT PRODUKTIF}

Pengelolaan harta zakat secara produktif bisa dilakukan dengan 
menyediakan sebuah usaha atau modal hidup untuk masyarakat. Kalau dilihat dari kondisi wilayah Indonesia yang lebih cenderung dalam kegiatan pertanian. Seperti yang terjadi pada masa kepresidenan Habibie. Indonesia sempat menjadi pusat penghasil beras dunia. Letak geografis dan keadaan tanah Indonesia sangat potensial akan tanaman.

Sebagai contoh yang bisa penulis contohkan yaitu tanaman kakao atau lebih dikenal dengan cokelat. Tanaman cokelat ini sangat potensial di wilayah kita. Di samping itu, harga jualnya relatif normal bisa menjadikan sebuah solusi untuk perubahan perekonomian masyarakat. Misalkan, 5.000.000 penduduk Indonesia mempunyai pendapatan $=2.500 .000 / \mathrm{bln}$

Jadi zakat yang diperoleh adalah $2.500 .000 \times 2.5 \%=62.500,-/$ orang. Dikalikan jumlah penduduk sehingga zakat yang diterima per bulan sebanyak 312.500.000.000,-Apabila dikumpulkan selama satu tahun menjadi Rp. 3.750.000.000.000,.Sebanyak Rp. 2.000.000.000.000,dijadikan untuk pembelian kakao. Sedangkan Rp. 750.000.000.000,dijadikan untuk pembelian pupuk penunjang pertumbuhan kakao. Sisanya dijadikan untuk zakat konsumtif bagi masyarakat yang benar-benar tidak mempunyai uang. Harga 1 batang kakao unggul Rp. 10.000,-. Jadi, kakao yang bisa disalurkan kepada masyarakat sebanyak 200.000.000 batang kakao dibagikan kepada 2 juta masyarakat Indonesia, masing-masing mendapat 200 batang bibit kakao dengan beberapa pupuk penunjangnya.
Pada pertumbuhan 8 bulan kakao sudah berbuah. Di atas 1 tahun sudah bisa menghasilkan buah lebih banyak. Katanya, 1 batang kakao akan menghasilkan buah 144 buah pertahun. Dikalikan dengan jumlah kakao, berarti buah yang akan dihasilkan selama satu tahun sebanyak 28.800 buah. Diperkirakan dalam satu hari (28.800/365) bisa menghasilkan buah sebanyak 78 buah, dalam satu bulan sebanyak 2.340 buah. 4 buah kakao beratnya 1 kilogram. Berarti ada $585 \mathrm{~kg}$. Apabila harga normal kakao Rp. 20.000 per kilogram. Maka penghasilan yang diperoleh per bulan sebanyak Rp. 11.700.000,-. Dikalikan setahun menjadi Rp. 140.400.000,-. Kemudian, mustahik zakat awalnya mengeluarkan zakat kembali sebanyak 2.5\% yaitu Rp. 3.510.000,-. Dikalikan sebanyak mustahik awal 2 juta orang, menjadi 7.020.000.000.000,-Itulah zakat tambahan yang akan muncul setelah mustahik diberikan zakat produktif. Tapi, tetap dipertahankan pengum-pulan zakat dari muzakki awal.

Kemudian, harta zakat dikelola lagi. Sangat jelas potensi zakat produktif bagi perekonomian masyarakat. Kemiskinan dan pengangguran berkurang serta muzakkimuzakki baru bermunculan. Perekonomian Indonesia akan kuat. Karena mayoritas masyarakatnya bekerja. Dan atas pekerjaannya akan ada penghasilan, kemudian akan tersisihkan sedikit pajak untuk Indonesia.

\section{PENUTUP}

Secara garis besar zakat produktif tersebut dapat dikelola, 
dikembangkan sedemikian rupa sehingga bisa mendatangkan manfaat (hasil), yang mana hasilnya tersebut akan digunakan untuk memenuhi kebutuhan para mustahik. Harta zakat juga bisa digunakan untuk investasi produktif. Pendayagunaan harta zakat secara produktif untuk konteks sekarang ini sangat diperlukan karena harta zakat ter-

\section{DAFTAR PUSTAKA}

Abdad, Zaidi. 2003. Lembaga Perekonomian Ummat di Dunia Islam, Bandung: Angkasa.

Ali, Mohammad Daud. 1988. Sistem Ekonomi Islam Zakat dan Wakaf, Jakarta: UI-Press.

Al Fauzan, Saleh. 2006. Fiqih Seharihari, Jakarta: Gema Insani.

Al Zuhayly, Wahbah. 1995. Al Fiqh Al IslamiAdillatuh, Damaskus: Dar Al Fikr.

Ar Rahman, Syaikh Muhammad Abdul Malik. 2003. 1001 Masalah Dan Solusinya, Jakarta: Pustaka Cerdas Zakat.

Doa, M. Djamal. 2004. Pengelolaan Zakat Oleh Negara Untuk Memerangi Kemiskinan, Jakarta: Nuansa Madani Publisher. sebut tidak habis begitu saja, melainkan bisa dikembangkan sesuai dengan kehendak dan tujuan dari syari'at zakat, yaitu menghilangkan kemiskinan serta mensejahterakan bagi kaum dhuafa, dengan harapan secara bertahap mereka tidak selamanya menjadi mustahiq melainkan beralih menjadi muzakki.

Hasan, M. Ali. 1997. Zakat, Pajak, Asuransi dan Lembaga Keuangan.

Kaelany, Islam, Iman, dan Amal Saleh, (Jakarta: PT. Rineka Cipta, 2000)

Khasanah, Umrotul. 2010. Manajemen Zakat Modern, Malang: UINMaliki Press.

Mufraini, M. Arif. 2008. Akuntansi dan Manajemen Zakat, Jakarta: Kencana.

Rafi', Mu'inan. 2011. Potensi Zakat, Yogyakarta: Citra Pustaka.

Rasyid, Sulaiman. 1994. Fiqih Islam, Bandung: Sinar Baru Algesindo.

Yunus, Mahmud. 1989. Kamus ArabIndonesia, Jakarta: PT. Hidakarya Agung. 